\title{
基本健康診査歴の保管と活用について 一伊勢原市における実態と光カードによる管理の試み一
}

坂間晃

伊勢原市では 60 歳以上の住民に対する基本健 康診査は施設健診として行われてきた。今回，こ の施設健診について医療機関および受診者の双方 に健診結果の保管と活用を中心としたアンケート 調査を行ったのでその結果を報告する。さらに， 伊勢原市で構築中の光カードによる個人の健康歴 の管理について，その現状を紹介する。

\section{1. 基本健診の現状}

60 歳以上の基本健診対象者は, 誕生月に市から 個別通知があり, 東海大学病院を除く市内各医療 機関（主として開業医）で健診を受けることがで きる。90 年度の受診者は伊勢原市の資料によると 3,748 人で，これは健診対象者の $34.1 \%$ にある 高率であった。

基本健診の記録表は B 4 版で市役所提出用・医 療機関控え・受診者用の 3 枚複写になっている。 健診の内容は厚生省の規準により身体所見・検 尿・GOT・GPT・総コレステロールを必須検査と し, 選択検査として心電図・眼底・血糖・貧血検 查があり,さらに確定診断検査として胸部 X 線写 真・赤沈・蛋白分画・尿酸・AL-P・中性脂肪・HDLCの諸検査を行える。また当市は県の腎疾患対策 のモデル地区となっており，検尿で異常があった 場合は公費で 2 次検尿が行える。

Useful data filing for the periodical results of "Kihon Kenkohsinsa" (Health examination for the aged) in Isehara city - current opinions of doctors or examinee participated in its health examination, and an experimental use of optical memory card system for data record.

秦野伊勢原医師会

\section{2. 医療機関アンケート結果}

医療機関へのアンケート調査は, 91 年 10 月上 旬に郵送により行った。調査対象は市内の 33 医療 機関で, 回答のあった 32 機関のうち基本健診を行 わなかったか, 受診者が数名までの 11 機関を除く 21 機関 (総合病院 1 , 内科系診療所 17 , 外科系診 療所 3）の集計結果を検討した。

基本健診の記録の管理方法を, 記録表, 心電図・ 眼底写真, $\mathrm{X}$ 線写真に分けてたずねた結果はカル テと別に年度別に保管するところが $60 \%$ 以上で あった。画像診断を個人別に管理しているところ は, 約 3 割であった。

健診が疾病の早期発見に役立ったと回答したも のは $75 \%$ で，そのうち過去の健診デー夕との比較 が役に立ったとするものは 75\%であった。この結 果から見ると基本健診は疾病や異常の早期発見と いう点で有効である。

基本健診で異常なかったがその後に疾病を発見 した経験のある機関は 4 割で, そのうち過去の健 診データと比較しなかったための見逃しがあった

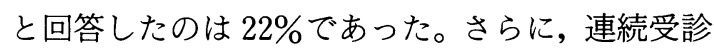
者の健診に際し過去のデータを参照するか聞いた ところ, 必ず参照すると回答した機関は 3 割弱で, 異常があった場合に参照するとしたのが 4 割であ った。残りの 3 割はなるべく参照するように努力 していると回答している。

健診結果の通知は医師が説明し，記録表を渡し ているところが大多数であったが，パソコンでデ ータベースを作成した結果を受診者に見せて説明 していると回答したところもあった。受診結果の 説明は各医療機関とも丁寧に行っていることがう 


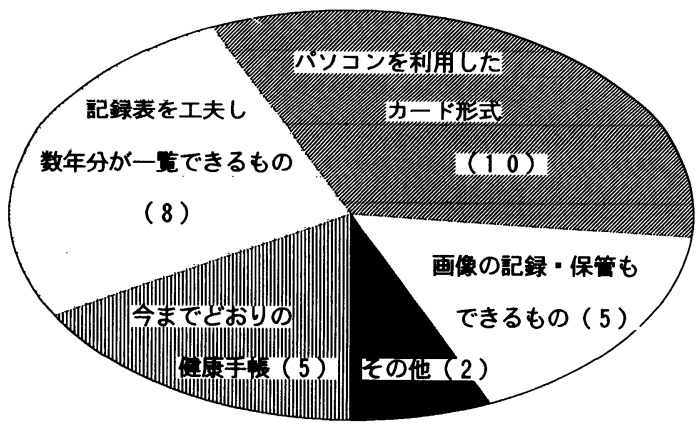

図 1 基本健診の記録管理システムとして何が良いか (医師・複数回答)

かがえる。

医療機関側から見て基本健診の記録管理には何 が良いかたずねた結果を図 1 に示す。これを見る と連続記録を縦覧できるようなシステムを期待し ていることが分かる。また画像の記録・保管を簡 便にしたいという要望もあった。画像診断に関し ては筆者にも苦い経験があり，過去の記録と簡単 に比較できるような方法が期待される。

\section{3. 基本健診受診者アンケート結果}

医療機関のアンケート調査と並行して, 健診受 診者の調査を行った。調査対象は 90 年度に筆者の 診療所で基本健診を受けた者のうち, 受診時に当 診療所に通院していなかった者 138 名である。以 下，有効回答のあった 98 名（男 43 名・女 55 名， 60 歳代 58 名 $\cdot 70$ 代 33 名. 80 代 7 名）の集計結果 につき検討した。

調査対象者の $88 \%$ が連続受診しているが, 連続 受診者で前の検診結果を持参した者は $26 \%$ であ つた。結果を持参した者の健診記録の保管方法は, 記録表を経っておいた者が $59 \%$ で，健康手帳に転

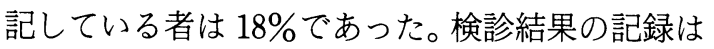
医療機関に任せるとした意見が 1 割あった。

他の医療機関に受診の際，健診結果を聞かれた ことがあるものは $36 \%$ あ゙あた。また，連続受診 による検査結果の相違から疾病が見つかったもの は $11 \%$ であった。さらに調査対象者の半数が他の 検診を受けていたが，その $85 \%$ はがん検診で，基 本健診と他の検診をうまく使い分けていることが 分かる。
基本健診記録の有効利用のためには，携帯しや すく見やすい記録媒体を望む者が $75 \%$ を占めて いた。

\section{4. 健診結果と行政の対応}

基本健診の結果，保健婦による指導を必要とし たものは 90 年度受診者の $19.8 \%$ で, 食事指導の 対象者が大半を占めていた。行政側では貧血教 室・高血圧教室・糖尿病教室等による集団指導や, 家庭訪問による個人指導を行い健診結果の有効利 用を計っている。

\section{5. 光カードシステムの現状}

以上，現在の伊勢原市における基本健診の実態 を，とくに健診記録の保管と活用という面から考 察してきたが，健診記録の新しいメディアとして の光カードシステムについて紹介する。

伊勢原市では 86 年より医師会・東海大学・行政 の 3 者によるすこやかカード研究会が中心となっ て，光カードを使用して健診結果を記録・表示す る実験を行ってきた。90 年度からは 51 名のモ二 ターに光カードを携帯させ, 毎月 1 回ミ二健診を 行い蓄積されたデー夕を表示するよう試みた。9 年 11 月時点でのモニターのアンケート調査では 実用化されたらすぐにでも利用したいという者が $88 \%$ を占めていた。一方，90 年 7 月から市内 3 医 療機関で慢性疾患患者に対してフロッピーカード を使用して診療結果と健診記録の管理を行ってみ た。 1 年後の調查では患者の継続治療のための動 機付けとして極めて有効であった。

以上の実験の成果を踏まえ, 伊勢原市は通産省 の指定事業として, 90 年度からは光カードを利用 した健康・福祉情報システムの開発に着手し，91 年度内に 65 歳以上 1,000 名の市民を対象に試験 運用が開始される。当面は図 2 の左上段に示す部 分の情報を入力する作業が行われている。基本健 診の記録はこの中にファイルされ，所定の場所で 出力できるようにされている。今後は医療情報の 記録や表示についてさらに改良発展が期待され る。 


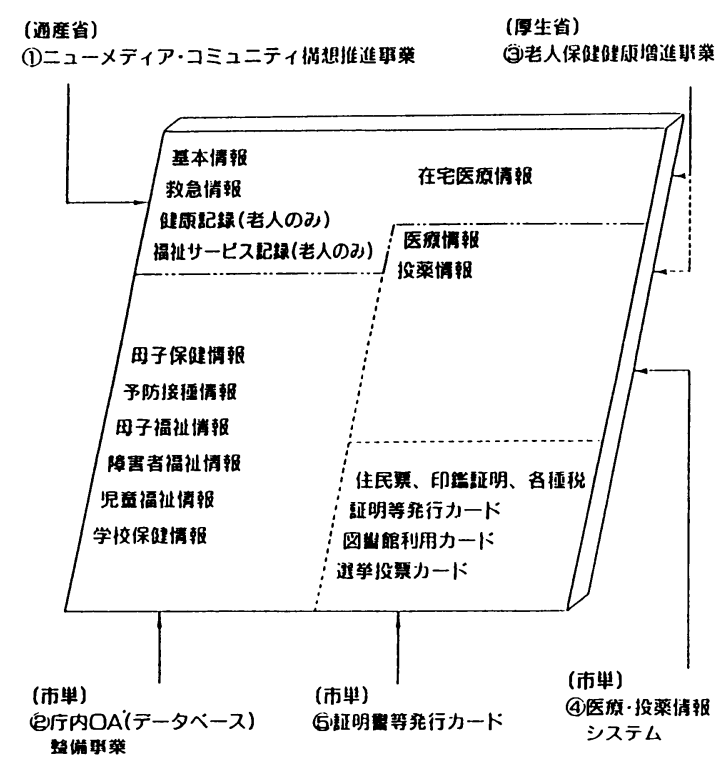

図 2 伊勢原市健康福祉情報システム

\section{6. 結論}

（a）基本健診記録の蓄積は疾病の早期発見に役 立っている。

（b）記録の保管と活用のためには情報の連続記 録と閲覧しやすさ・携帯性が重視される。 (c) 画像診断記録の保管に工夫が必要である。

（d）上記の要件を満たす 1 つの方法として光力 ードの利用は今後有効な手段となりうる。

アンケート調査にご協力いただいた医師会諸先 生，市民に感謝致します。 